\title{
Systematic Review \\ Oncological Response and Predictive Biomarkers for the Checkpoint Inhibitors in Castration-Resistant Metastatic Prostate Cancer: A Systematic Review and Meta-Analysis
}

\author{
Omar Fahmy ${ }^{1}$, Nabil A. Alhakamy ${ }^{2,3,4,5}{ }^{\mathbb{D}}$, Mohd G. Khairul-Asri ${ }^{1}$, Osama A. A. Ahmed ${ }^{2,4} \mathbb{D}^{\mathbb{D}}$, \\ Usama A. Fahmy ${ }^{2}$ (D) Claudia G. Fresta ${ }^{6}$ and Giuseppe Caruso ${ }^{7, *(D)}$ \\ 1 Department of Urology, University Putra Malaysia, Seri Kembangan 43400, Malaysia; \\ omarfahmy.ahmed@upm.edu.my (O.F.); khairulasri@upm.edu.my (M.G.K.-A.) \\ 2 Department of Pharmaceutics, Faculty of Pharmacy, King Abdulaziz University, Jeddah 21589, Saudi Arabia; \\ nalhakamy@kau.edu.sa (N.A.A.); oaahmed@kau.edu.sa (O.A.A.A.); uahmedkauedu.sa@kau.edu.sa (U.A.F.) \\ 3 Advanced Drug Delivery Research Group, Faculty of Pharmacy, King Abdulaziz University, Jeddah 21589, \\ Saudi Arabia \\ 4 Center of Excellence for Drug Research and Pharmaceutical Industries, King Abdulaziz University, \\ Jeddah 21589, Saudi Arabia \\ 5 Mohamed Saeed Tamer Chair for Pharmaceutical Industries, King Abdulaziz University, \\ Jeddah 21589, Saudi Arabia \\ 6 Department of Biomedical and Biotechnological Sciences, University of Catania, 95125 Catania, Italy; \\ forclaudiafresta@gmail.com \\ 7 Department of Drug and Health Sciences, University of Catania, 95125 Catania, Italy \\ check for
} updates

Citation: Fahmy, O.; Alhakamy, N.A.; Khairul-Asri, M.G.; Ahmed, O.A.A.; Fahmy, U.A.; Fresta, C.G.; Caruso, G. Oncological Response and Predictive Biomarkers for the Checkpoint Inhibitors in Castration-Resistant Metastatic Prostate Cancer: A Systematic Review and Meta-Analysis. J. Pers. Med. 2022, 12, 8. https://doi.org/10.3390/ jpm12010008

Academic Editor: Wojciech Krajewski

Received: 30 November 2021 Accepted: 20 December 2021 Published: 23 December 2021

Publisher's Note: MDPI stays neutral with regard to jurisdictional claims in published maps and institutional affiliations.

Copyright: (c) 2021 by the authors. Licensee MDPI, Basel, Switzerland. This article is an open access article distributed under the terms and conditions of the Creative Commons Attribution (CC BY) license (https:// creativecommons.org/licenses/by/ $4.0 /)$.
Abstract: Recently, checkpoint inhibitors have been investigated in metastatic prostate cancer, however their overall effect is unclear and needs to be further investigated. Objectives: The aim of this systematic review is to investigate the oncological response of metastatic castration-resistant prostate cancer patients to immune checkpoint inhibitors. Methods: Based on the preferred reporting items for systematic reviews and meta-analyses (PRISMA) statement, a systematic review of the literature was conducted through online electronic databases and the American Society of Clinical Oncology (ASCO) Meeting Library. Eligible publications were selected after a staged screening and selection process. RevMan 5.4 software was employed to run the quantitative analysis and forest plots. Risk of bias assessment was conducted using the Cochrane tool and Newcastle-Ottawa Scale for the randomized and non-randomized trials, respectively. Results: From the 831 results retrieved, 8 studies including 2768 patients were included. There was no significant effect on overall survival (OS) (overall response $(\mathrm{OR})=0.98 ; \mathrm{Z}=0.42 ; p=0.67)$. Meanwhile, progression-free survival (PFS) was significantly better with immune checkpoint inhibitors administration $(\mathrm{OR}=0.85 ; \mathrm{Z}=3.9 ; p<0.0001)$. The subgroup analysis for oncological outcomes based on programmed death ligand 1 (PD-L1) positivity status displayed no significant effect, except on prostate-specific antigen response rate (PSA RR) (OR = 3.25; $Z=2.29 ; p=0.02$ ). Based on DNA damage repair (DDR), positive patients had a significantly better PFS and a trend towards better OS and overall response rate (ORR); the ORR was $40 \%$ in positive patients compared to $20 \%$ in the negative patients $(\mathrm{OR}=2.46 ; \mathrm{Z}=1.3 ; p=0.19)$, while PSA RR was $23.5 \%$ compared to $14.3 \%(\mathrm{OR}=1.88 ; \mathrm{Z}=0.88 ; p=0.38)$. Better PFS was clearly associated with DDR positivity $(\mathrm{OR}=0.70 ; \mathrm{Z}=2.48 ; p=0.01$ ) with a trend towards better $\mathrm{OS}$ in DDR positive patients $(\mathrm{OR}=0.71 ; \mathrm{Z}=1.38 ; p=0.17)$. Based on tumor mutation burden (TMB), ORR was $46.7 \%$ with high $\mathrm{TMB}$ versus $8.8 \%$ in patients with low $\mathrm{TMB}(\mathrm{OR}=11.88 ; \mathrm{Z}=3.0 ; p=0.003)$. Conclusions: Checkpoint inhibitors provide modest oncological advantages in metastatic castration-resistant prostate cancer. There are currently no good predictive indicators that indicate a greater response in some patients.

Keywords: prostate cancer; immune checkpoint inhibitors; immunotherapy; metastatic castrationresistant prostate cancer 


\section{Introduction}

Prostate cancer was the second most frequent cancer and the fifth largest cause of cancer-related deaths among males globally in 2020 [1]. Therapeutic options for advanced prostate cancer have expanded in the last few years as a result of a better knowledge of the molecular processes that underpin metastatic spread, particularly the crucial involvement of the tumor microenvironment [2]. Prostate cancer is incurable once it has spread to other parts of the body [3]. The long-standing standard of therapy for metastatic prostate cancer is androgen deprivation [4]. Aside from androgen deprivation therapy (ADT), which is the cornerstone of metastatic prostate cancer care, therapeutic options mostly consist of either innovative hormonal therapies (abiraterone, enzalutamide, and apalutamide) or taxane-based chemotherapy (docetaxel and cabazitaxel) [5,6]. Castrate-resistant prostate cancer (CRPC) develops when tumors cease responding to androgen deprivation. Docetaxel, cabazitaxel, abiraterone, enzalutamide, sipuleucel-T, and the bone-specific radionuclide radium-223 represent all therapy possibilities for individuals with metastatic CRPC (mCRPC). These treatments are not curative and may have a low tolerability [7].

Given the limited therapy choices for the vast majority of patients and the promising results of immune checkpoint inhibitors (ICIs) in other advanced diseases such as melanoma and lung cancer, there is a growing emphasis on treating prostate cancer with ICIs [8,9]. Although immune checkpoint blockade has been shown to be effective in urothelial and renal-cell carcinomas $[10,11]$, prostate cancer has a more immunosuppressive microenvironment than these other genitourinary malignancies, suggesting that mCRPC may be less susceptible to immune checkpoint blockade [12,13].

The aim of this systematic review is to investigate the oncological response of $\mathrm{mCRPC}$ to ICIs. In addition, we explored several potential predictive biomarkers that could help in patient selection for future trials to maximize the benefit coming from drug treatment.

\section{Materials and Methods}

\subsection{Search Strategy}

Following the preferred reporting items for systematic reviews and meta-analyses (PRISMA) criteria [14,15], we conducted online systemic search through online electronic databases (PubMed, EMBASE, Wiley Online Library, and Cochrane databases). The following keywords were utilized during the search: metastatic prostate cancer; immunotherapy; checkpoint inhibitors; castration-resistant. Exclusion criteria were: (1) review articles; (2) case reports; (3) letters to editors and editorial comments; (4) repeated publications; (5) noncontrolled trials without subgroup analysis for the oncological outcomes; (6) non-English articles; (7) trials on other prostate cancer cohorts rather than mCRPC. All results initially assessed by the title, with or without abstract assessment, were followed by full-text assessment. Eventually, we included the controlled trials reported on checkpoint inhibitors in $\mathrm{mCRPC}$, or non-controlled trials but with subgroup analysis and comparisons.

\subsection{Data Extraction}

Data was independently extracted by two authors and checked by a third one: total number of patients, trial number, type and status, patients' criteria, investigated drugs, overall response rates (ORR), prostate-specific antigen response rate (PSA RR), overall survival (OS), progression free survival (PFS), follow-up duration. ORR was defined as number of patients with partial or complete response to treatment according to the response evaluation criteria in solid tumors (RECIST) 1.1 criteria [16]. PSA RR was defined as reduction of PSA by at least $50 \%$ from the baseline. Both previous definitions were used in all the included studies. Subgroups' oncological outcomes were based on the investigated biomarkers such as programmed death ligand 1 (PD-L1) status, DNA damage repair (DDR) status, and tumor mutation burden (TMB). Dichotomous data were extracted as number of events and total numbers. Survival data were extracted as hazard ratio (HR) and $95 \%$ confidence interval (CI). When HR and CI were not reported, Tierney's method was employed to estimate the HR and CI from Kaplan-Meier curves [17]. 


\subsection{Primary Outcomes}

The primary outcome of this systematic review and meta-analysis was to investigate the oncological response of $\mathrm{mCRPC}$ to checkpoint inhibitors and the biomarkers associated with a better response.

\subsection{Statistical Analysis}

The Nordic Cochrane Centre (Cochrane Collaboration, Copenhagen) employed Review Manager (RevMan) software version 5.4 (Cochrane library, London, UK)) for statistical analysis and the creation of forest plots for this meta-analysis. For time to event data (OS, PFS) we calculated the OR with 95\% CI using Log HR and standard error (SE). For dichotomous data (ORR, PSA RR) we calculated the OR with 95\% CI using number of events and total numbers. The $\mathrm{I}^{2}$ value was used to determine the heterogeneity of the research. For $\mathrm{I}^{2}<50 \%$ fixed effect model was used, while in the case of $\mathrm{I}^{2} \geq 50 \%$ random effect model was examined. The Z-test was used to assess the overall impact. $p$-values $<0.05$ were considered significant in all tests [18].

\subsection{Risk of Bias Assessment}

For randomized trials, Cochrane bias assessment module of RevMan 5.4 software was employed. For non-randomized trials, Newcastle-Ottawa Scale was employed and scores of 7-9, 4-6, and 4 were classified as having a low, moderate, or high risk of bias, respectively (http:/ / www.ohri.ca/programs/clinical_epidemiology/oxford.asp (accessed on 5 October 2021)).

\section{Results}

\subsection{Search Results}

Initial search in electronic databases revealed 831 results which underwent initial assessment. Twenty three publications underwent full-text assessment, and finally, eight publications (six journal papers [19-24], and two meeting abstracts [25,26]) were considered. A total number of 2768 patients with $\mathrm{mCRPC}$ were included in the pooled analyses, after exclusion of one cohort ( $n=59$ patients) from one study not eligible for subgroup analysis [21]. The flow of screening and selection process is showed in Figure 1, while the summary of the included studies is provided in Table 1.

Risk of bias assessment is available in Table 2 for the five non-randomized trials [19-22,26], and in Figure 2 for the three randomized trials [23-25]. 
Online search through electronic databases (Pubmed, EMBASE, Web of Science, Wiley online library, and Cochrane databases) \& American Society of Clinical Oncology (ASCO) Meeting Library
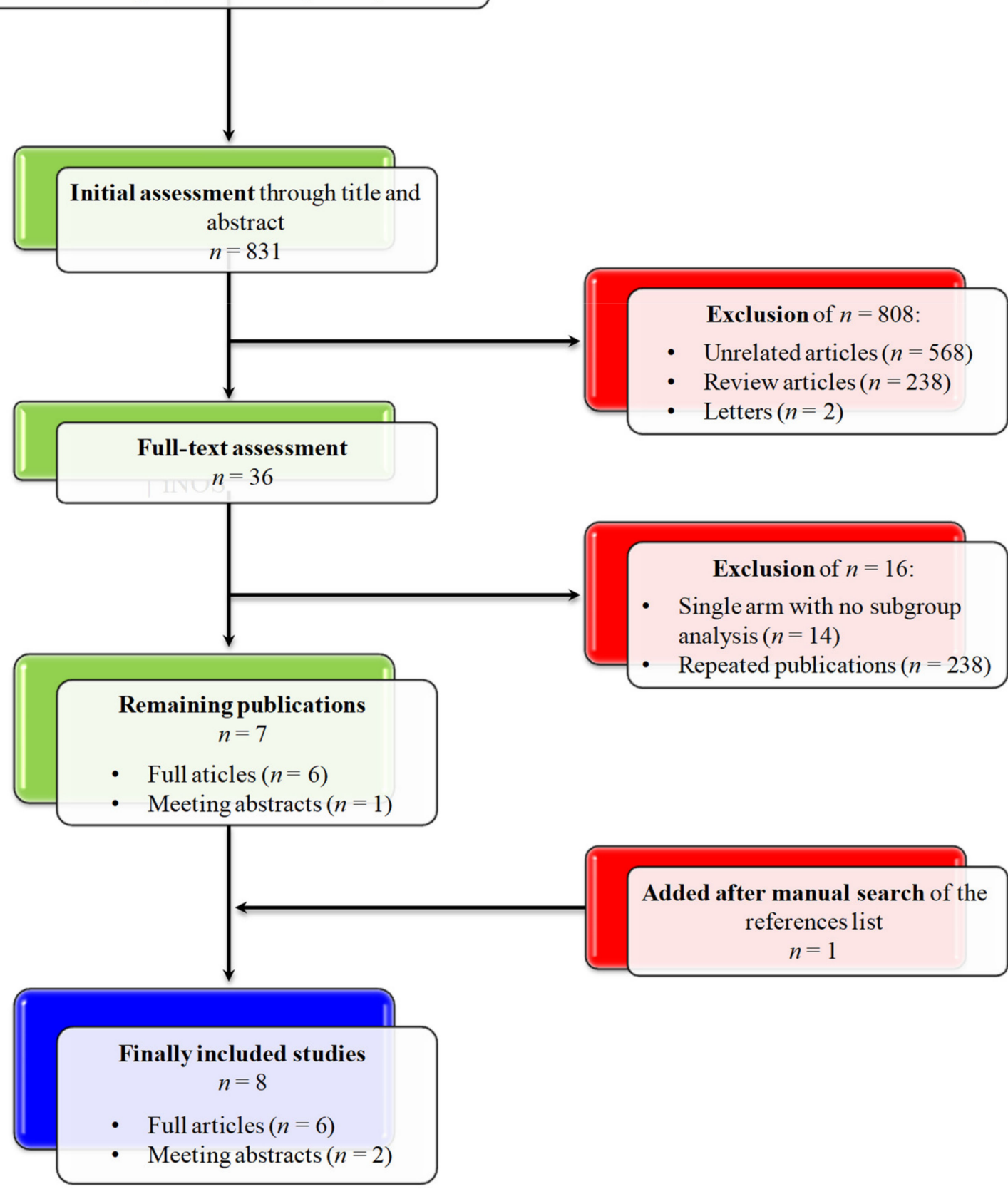

Figure 1. CONSORT diagram for the screening and selection processes of the included studies. 
Table 1. Summary of the included studies. $\mathrm{MCRPC}$, metastatic castration-resistant prostate cancer; ADT, androgen deprivation therapy; ORR, overall response rate; PSA, prostate-specific antigen; RECIST, response evaluation criteria in solid tumors; OS, overall survival; PD- L1, programmed death ligand 1.

\begin{tabular}{|c|c|c|c|c|c|c|c|}
\hline Study & $\begin{array}{l}\text { NCT ID/Trial } \\
\text { Name }\end{array}$ & $\begin{array}{l}\text { Phase and } \\
\text { Status }\end{array}$ & Patient Criteria & $\begin{array}{c}\text { Number } \\
\text { of Patients }\end{array}$ & Drug & $\begin{array}{l}\text { Primary } \\
\text { Endpoint }\end{array}$ & Outcome \\
\hline $\begin{array}{l}\text { Antonarakis } \\
2020[21]\end{array}$ & $\begin{array}{l}\text { NCT02787005 } \\
\text { (KEYNOTE-199) }\end{array}$ & $\begin{array}{l}\text { Phase II, } \\
\text { active, not } \\
\text { recruiting }\end{array}$ & $\begin{array}{c}\text { mCRPC with previous } \\
\text { docetaxel and targeted ADT. } \\
\text { Cohort1 (PD-L1-positive) } \\
\text { Cohort } 2 \text { (PD-L1-negative). } \\
\text { Cohort } 3 \text { (bone-predominant } \\
\text { disease, regardless of PD-L1) }\end{array}$ & $\begin{array}{l}133 \text { (cohort } 1) \\
66 \text { (cohort 2) } \\
59(\text { cohort } 3)\end{array}$ & Pembrolizumab & ORR by RECIST 1.1 & $\begin{array}{c}\text { ORR was } 5 \% \text { (cohort } 1) \text { vs. } 3 \% \\
\text { (cohort } 2)\end{array}$ \\
\hline $\begin{array}{l}\text { Sharma } \\
2020[19]\end{array}$ & $\begin{array}{l}\text { NCT02985957, } \\
\text { (CheckMate 650) }\end{array}$ & $\begin{array}{l}\text { Phase II, } \\
\text { recruiting }\end{array}$ & $\begin{array}{l}\text { mCRPC Cohort } 1 \text { (pre-chemo.) } \\
\text { cohort } 2 \text { (post-chemo.) }\end{array}$ & $\begin{array}{l}45 \text { (cohort 1) } \\
45 \text { (cohort 2) }\end{array}$ & $\begin{array}{l}\text { Nivolumab + } \\
\text { ipilimumab }\end{array}$ & $\begin{array}{l}\text { ORR at } 6 \text { months, } \\
\text { (rPFS) at } 12 \text { months }\end{array}$ & $\begin{array}{l}\text { ORR }-25 \% \text { and } 10 \% \text {, median } \\
\text { PFS }-5.5 \text { and } 3.8 \text { months in } \\
\text { cohort } 1 \text { and } 2 \text {, respectively }\end{array}$ \\
\hline $\begin{array}{l}\text { Sweeney } \\
2020[25]\end{array}$ & $\begin{array}{l}\text { NCT03016312 } \\
\text { (IMbassador250) }\end{array}$ & $\begin{array}{l}\text { Phase III, } \\
\text { active, not } \\
\text { recruiting }\end{array}$ & $\begin{array}{c}\text { mCRPC after the failure of an } \\
\text { androgen synthesis inhibitor } \\
\text { and failure/ineligibility/refusal } \\
\text { of a taxane regimen }\end{array}$ & 759 & $\begin{array}{l}\text { Atezolizumab + } \\
\text { enzalutamide vs. } \\
\text { enzalutamide only }\end{array}$ & OS & $\begin{array}{c}\text { Median OS } 15.2 \text { vs. } \\
16.6 \text { months, respectively }\end{array}$ \\
\hline $\begin{array}{c}\text { Hotte } \\
2019[26]\end{array}$ & NCT02788773 & $\begin{array}{c}\text { Phase II, } \\
\text { active, } \\
\text { not recruiting }\end{array}$ & $\begin{array}{c}\text { mCRPC after prior } \\
\text { abiraterone and/or } \\
\text { enzalutamide, and no more } \\
\text { than one taxane }\end{array}$ & 52 & $\begin{array}{l}\text { Durvalumab with or } \\
\text { without } \\
\text { tremelimumab }\end{array}$ & $\begin{array}{l}\text { ORR measured } \\
\text { by RECIST } 1.1 \text { and } \\
\text { iRECIST }\end{array}$ & $\begin{array}{l}\text { ORR } 0 \%(0 / 13) \text { vs. } 16 \%(6 / 37) \\
\text { and PSA response rate } 0 \% \\
(0 / 13) \text { vs. } 16 \%(6 / 37) \text { in the } \\
\text { durvalumab arm vs. } \\
\text { durvalumab + } \\
\text { tremelimumab arm }\end{array}$ \\
\hline $\begin{array}{l}\text { Boudadi } \\
2018[20]\end{array}$ & $\begin{array}{l}\text { NCT02601014 } \\
\text { (STARVE-PC) }\end{array}$ & $\begin{array}{l}\text { Phase II, } \\
\text { active not } \\
\text { recruiting }\end{array}$ & mCRPC expressing AR-V7 & 15 & $\begin{array}{l}\text { Nivolumab + } \\
\text { ipilimumab }\end{array}$ & $\begin{array}{l}\text { Change in PSA } \\
\text { response }(>50 \% \\
\text { PSA decline) }\end{array}$ & PSA reponse-13.3\% $(2 / 15)$ \\
\hline $\begin{array}{c}\text { Karzai } \\
2018[22]\end{array}$ & NCT02484404 & $\begin{array}{l}\text { Phase I/II } \\
\text { Recruiting }\end{array}$ & $\begin{array}{l}\text { mCRPC previously treated } \\
\text { with enzalutamide and/or } \\
\text { abiraterone }\end{array}$ & 17 & Durvalumab + olaparib & $\begin{array}{l}\text { Improved PFS }(70 \% \\
\text { PFS vs. an estimated } \\
50 \% \text { at } 4 \text { months })\end{array}$ & $\begin{array}{c}\text { rPFS of } 51.5 \% \text { at } 12 \text { months } \\
\text { with a median rPFS of } \\
16.1 \text { months }\end{array}$ \\
\hline $\begin{array}{l}\text { Beer } 2017 \\
{[23]}\end{array}$ & $\begin{array}{l}\text { NCT01057810 } \\
\text { (CA184-095) }\end{array}$ & $\begin{array}{l}\text { Phase III, } \\
\text { completed }\end{array}$ & $\begin{array}{l}\text { Asymptomatic or minimally } \\
\text { symptomatic with } \\
\text { chemotherapy-naive mCRPC } \\
\text { without visceral metastases }\end{array}$ & 837 & $\begin{array}{l}\text { Ipilimumab } \\
\text { vs. placebo }\end{array}$ & OS & $\begin{array}{l}\text { Median OS } 28.7 \text { months vs. } \\
29.7 \text { months. No improvement } \\
\text { in OS with ipilimumab }\end{array}$ \\
\hline $\begin{array}{c}\text { Kwon } \\
2014[24]\end{array}$ & $\begin{array}{l}\text { NCT00861614 } \\
\text { (CA184-043) }\end{array}$ & $\begin{array}{l}\text { Phase III, } \\
\text { completed }\end{array}$ & $\begin{array}{c}\text { mCRPC with progression after } \\
\text { docetaxel }\end{array}$ & 799 & $\begin{array}{l}\text { Ipilimumab vs. placebo } \\
\text { after radiotherapy }\end{array}$ & OS & $\begin{array}{c}\text { Median OS } 11,2 \text { months vs. } \\
10 \text { months }\end{array}$ \\
\hline
\end{tabular}


Table 2. Newcastle-Ottawa Scale for risk of bias assessment of the non-randomized trials (scores $\geq 7-9,4-6,<4$ are considered as low, intermediate, and high risk, respectively).

\begin{tabular}{|c|c|c|c|c|c|c|c|c|c|}
\hline \multirow[t]{2}{*}{ Study } & \multicolumn{4}{|c|}{ Selection } & \multirow[t]{2}{*}{ Comparability } & \multicolumn{3}{|c|}{ Outcome } & \multirow[t]{2}{*}{ Overall } \\
\hline & $\begin{array}{l}\text { Representativeness } \\
\text { of Exposed Cohort }\end{array}$ & $\begin{array}{l}\text { Selection of } \\
\text { Not Exposed }\end{array}$ & $\begin{array}{l}\text { Ascertainment } \\
\text { of Exposure }\end{array}$ & $\begin{array}{l}\text { Outcome Not } \\
\text { Present at Start }\end{array}$ & & $\begin{array}{l}\text { Assessment } \\
\text { of Outcome }\end{array}$ & $\begin{array}{c}\text { Adequate } \\
\text { Follow-up Length }\end{array}$ & $\begin{array}{l}\text { Adequacy } \\
\text { of Follow-up }\end{array}$ & \\
\hline Antonarakis 2020 [21] & * & & * & $*$ & * & * & * & * & $7 / 9$ \\
\hline Hotte 2019 [26] & * & & & * & * & & * & * & $5 / 9$ \\
\hline Boudadi 2018 [20] & * & & * & * & * & * & * & * & $7 / 9$ \\
\hline Karzai 2018 [22] & * & & * & * & * & * & & * & $6 / 9$ \\
\hline
\end{tabular}

${ }^{*}$ Each item is assessed by one star and the comparability by two stars (the total is nine stars). 


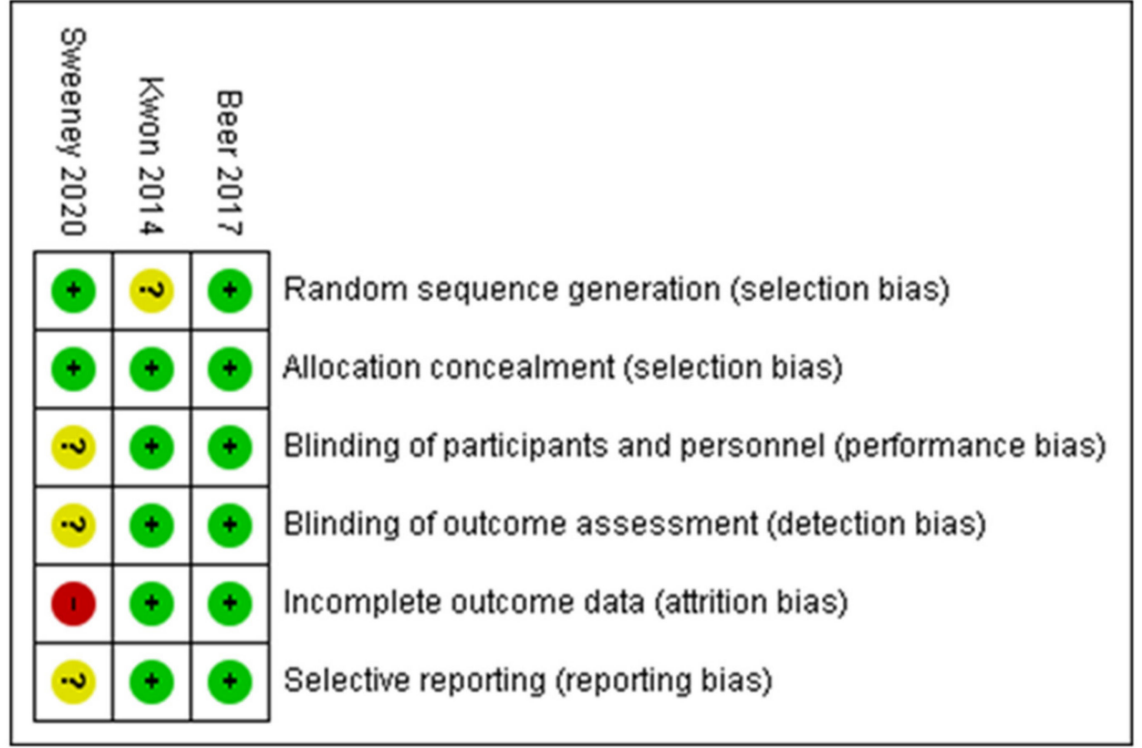

Figure 2. Risk of bias in the randomized trials (green $=$ low risk, yellow $=$ unclear, red $=$ high risk). Sweeney et al., 2020 [25], Kwon et al., 2014 [24], Beer et al., 2017 [23].

\subsection{OS and PFS}

The analysis of three randomized phase III studies including 2395 patients showed no significant effect of ICIs in improving the OS (OR $=0.98 ; Z=0.42 ; p=0.67)$ [23-25] (Figure 3A). Meanwhile, PFS form two randomized phase III studies with 1636 patients was significantly better with ICIs administration $(\mathrm{OR}=0.85 ; \mathrm{Z}=3.9 ; p<0.0001)[23,24]$ (Figure 3B).

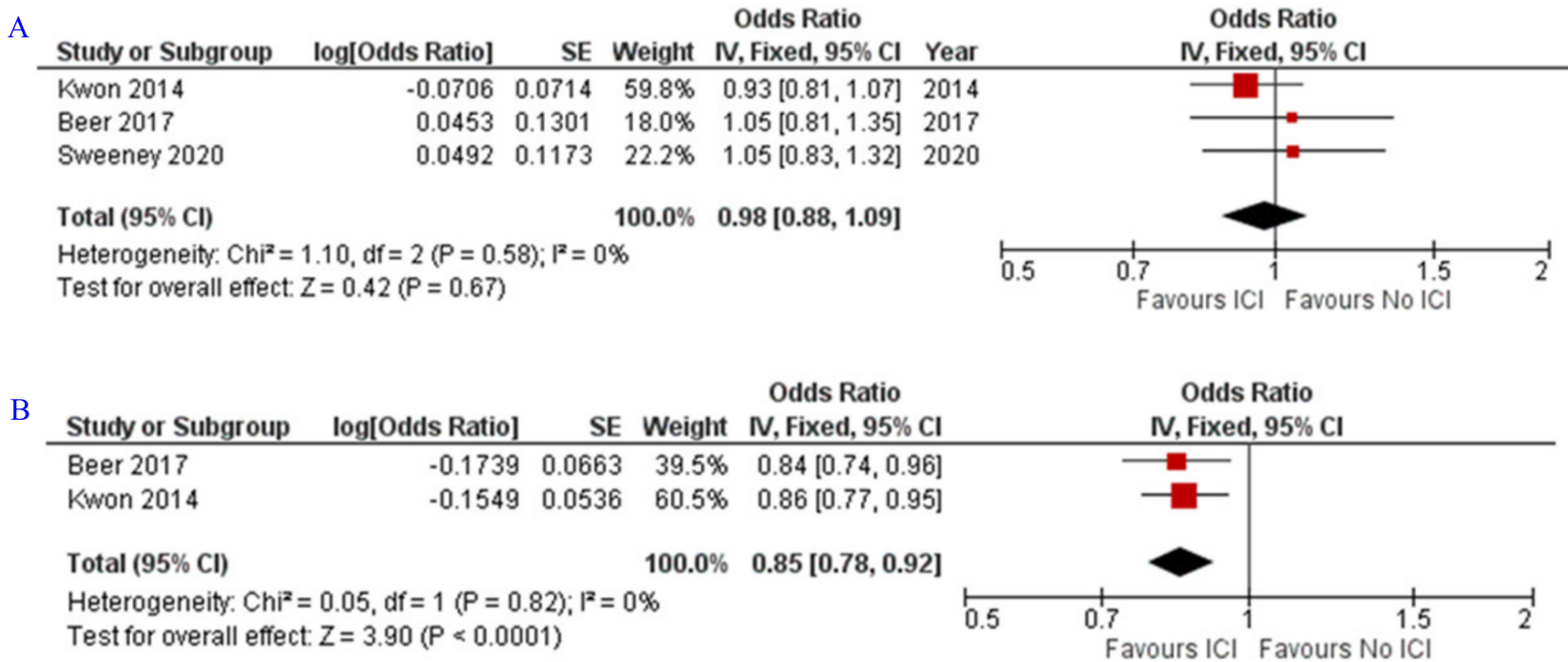

Figure 3. Forest plot for the impact of ICIs, on the (A) OS and (B) PFS. ICIs, immune checkpoint inhibitors; OS, overall survival; PFS, progression-free survival. Sweeney et al., 2020 [25], Kwon et al., 2014 [24], Beer et al., 2017 [23].

\subsection{Impact of PD-L1 Status on Oncological Response}

Subgroup analysis for oncological outcomes based on PD-L1 positivity status was feasible for ORR, PSA RR, OS, and PFS. There was no significant effect, except on ORR; PSA RR was $6.9 \%$ (9/131) in PD-L1 positive patients compared to $12.2 \%(11 / 90)$ in negative patients $(\mathrm{OR}=0.74 ; \mathrm{Z}=0.58 ; p=0.56)[19,21]$. For $\mathrm{ORR}$, despite a comparable rate $10.3 \%$ 
$(16 / 156)$ and $10.0 \%(13 / 129)$ in positive and negative, respectively, yet the pooled effect displayed significant association between the PD-L1 positivity and the ORR (OR $=3.25$; $\mathrm{Z}=2.29 ; p=0.02)[19,21,22,26]$. There was almost no impact on PFS $(\mathrm{OR}=0.99 ; \mathrm{Z}=0.06$; $p=0.95)[19,21]$ or $\mathrm{OS}(\mathrm{OR}=0.94 ; \mathrm{Z}=0.32 ; p=0.75)[19,21]$ (Figure 4$)$.

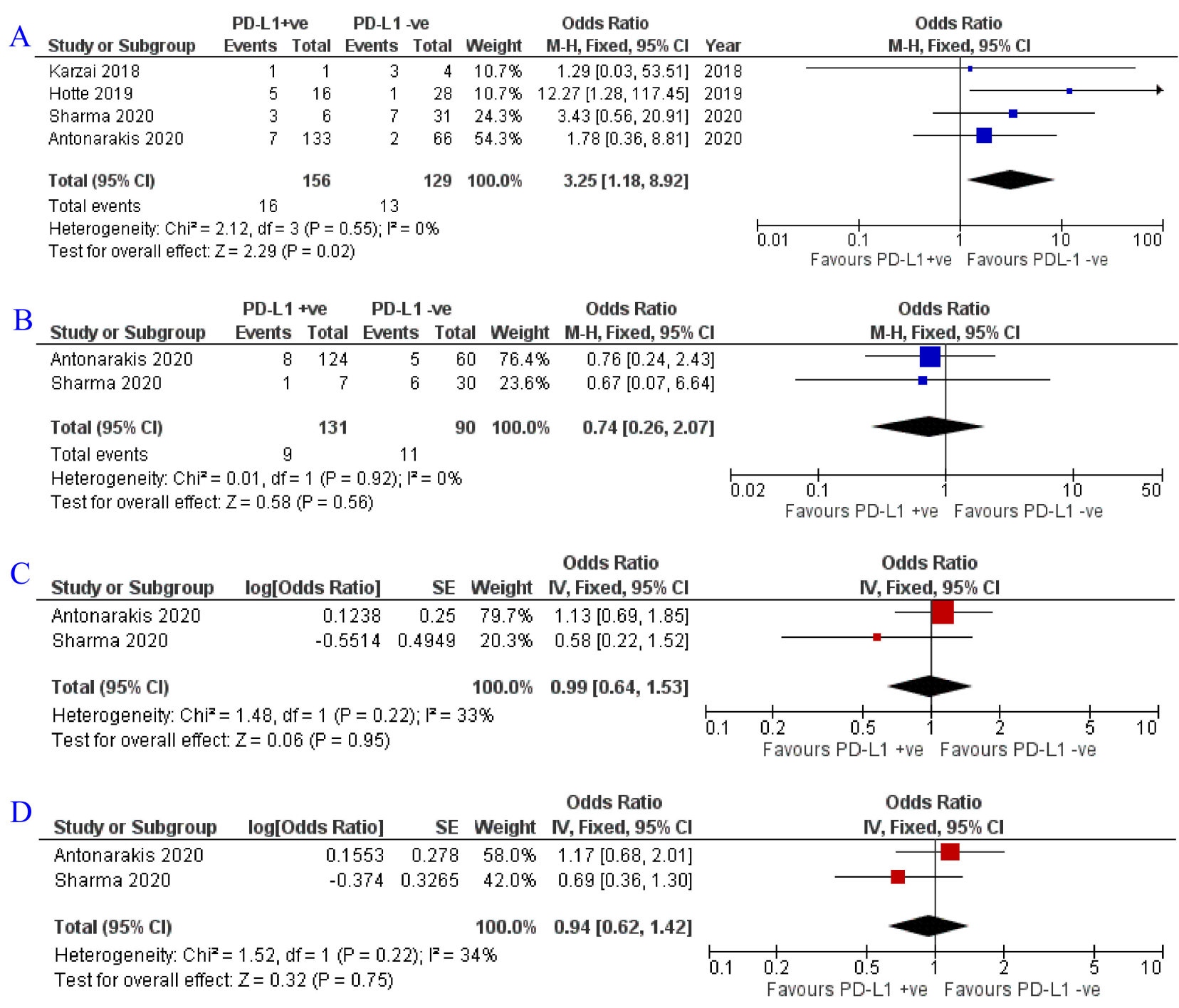

Figure 4. Forest plots for the impact of PD-L1 status on (A) ORR, (B) PSA RR, (C) PFS, and (D) OS. PD- L1, programmed death ligand 1; ORR, overall response rate, PSA RR, prostate-specific antigen response rate. Antonarakis et al., 2020 [21], Sharma et al., 2020 [19], Hotte et al., 2019 [26], Karzai et al., 2018 [22].

\subsection{Impact of DDR Status on Oncological Response}

A similar subgroup analysis was conducted based on DDR positivity. Positive patients had a significantly better PFS and a trend towards better OS and ORR; the ORR was $40 \%$ $(6 / 15)$ in positive patients compared to $20 \%(6 / 29)$ in the negative patients $(\mathrm{OR}=2.46$; $Z=1.3 ; p=0.19)[19,20]$. PSA RR was $23.5 \%(4 / 17)$ compared to $14.3 \%(5 / 35)$, however not significant $(\mathrm{OR}=1.88 ; \mathrm{Z}=0.88 ; p=0.38)[19,20]$. In three studies including 122 patients, better PFS was clearly associated with DDR positivity $(\mathrm{OR}=0.70 ; \mathrm{Z}=2.48$; $p=0.01)[19,20,22]$. With regard to OS, two studies with 105 patients displayed a trend towards better OS in DDR positive patients $(\mathrm{OR}=0.71 ; \mathrm{Z}=1.38 ; p=0.17)[19,20]$ (Figure 5). 


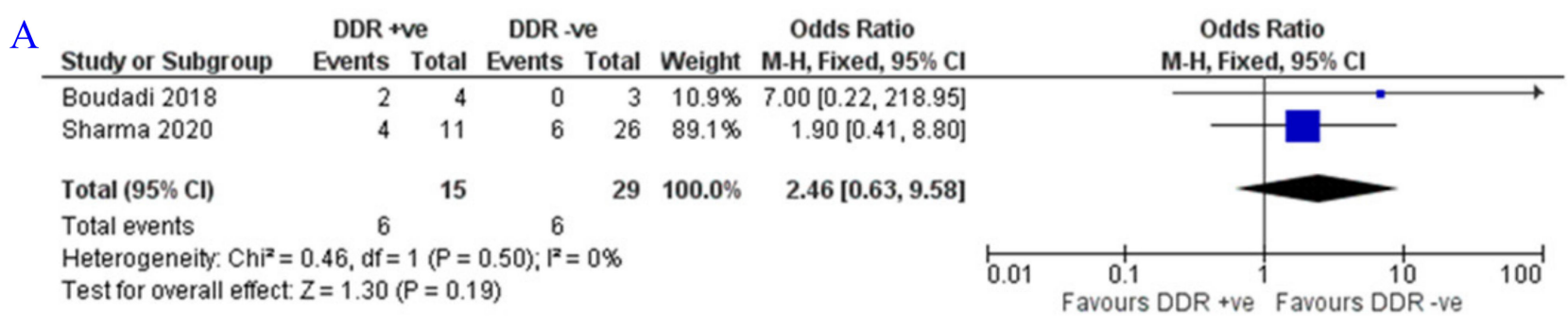

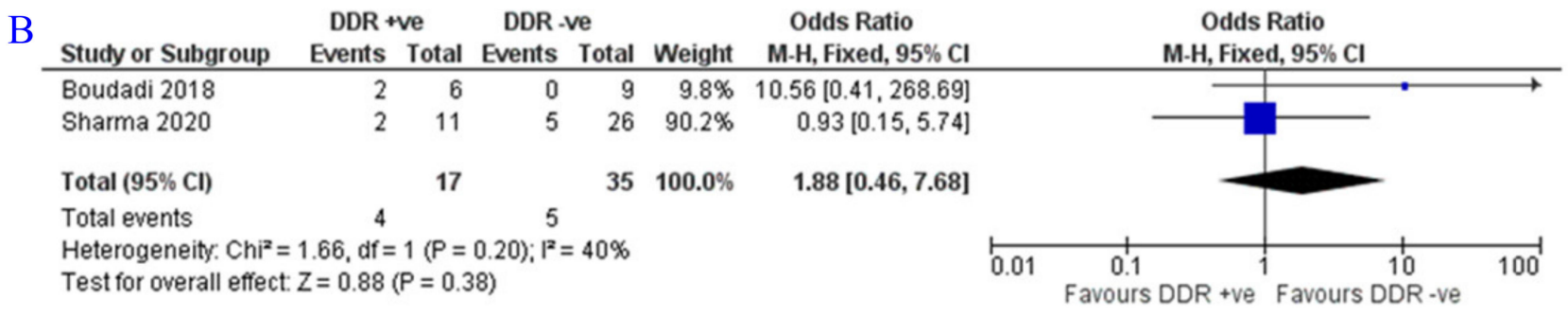

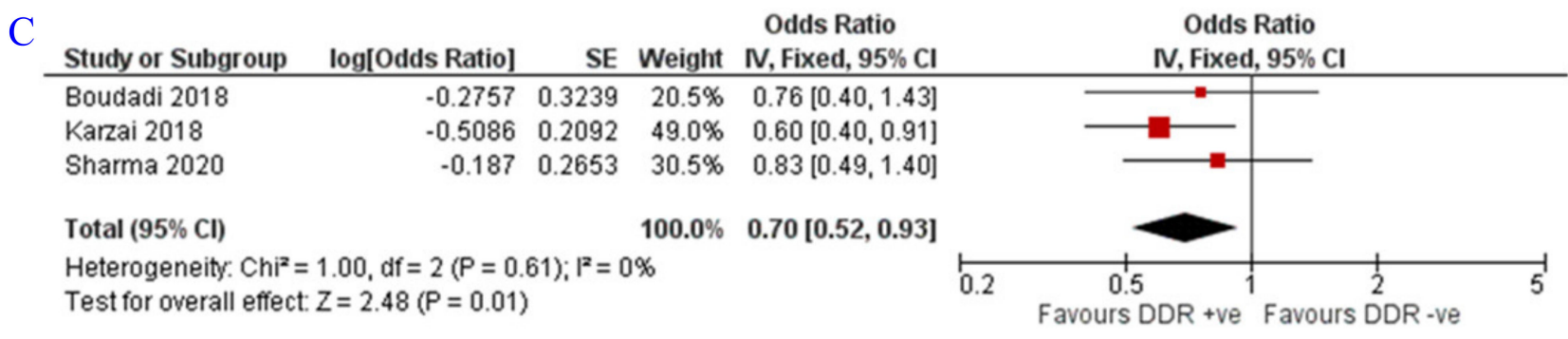

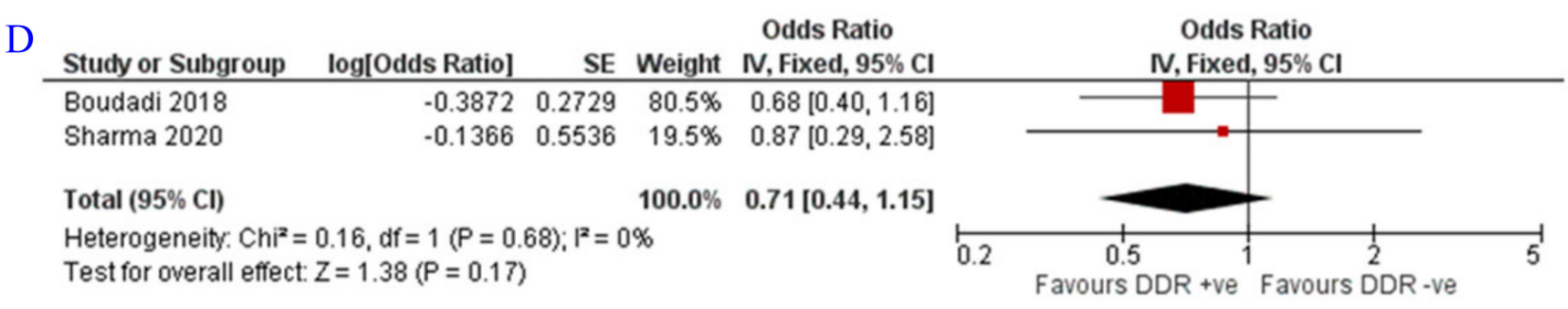

Figure 5. Forest plots for the impact of DDR status on (A) ORR, (B) PSA RR, (C) PFS, and (D) OS. DDR, DNA damage repair. Sharma et al., 2020 [19], Boudadi et al., 2018 [20], Karzai et al., 2018 [22].

\subsection{Impact of TMB on Oncological Response}

Subgroup analysis based on TMB was only feasible for ORR. Higher ORR was clearly associated with higher TMB. In a total of 78 patients from two studies, the ORR was $46.7 \%$ $(10 / 21)$ with high TMB compared to $8.8 \%(5 / 57)$ in patients with low TMB $(\mathrm{OR}=11.88$; $\mathrm{Z}=3.0 ; p=0.003$ ) $[19,26]$ (Figure 6).

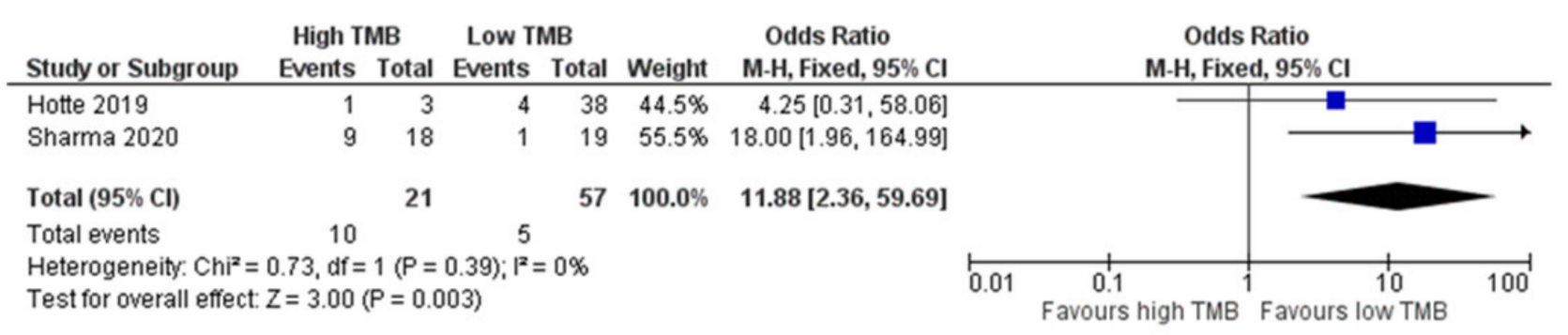

Figure 6. Forest plots for the impact of TMB on ORR. TMB, tumor mutation burden. Sharma et al., 2020 [19], Hotte et al., 2019 [26]. 


\section{Discussion}

About $6 \%$ of prostate cancer patients have metastatic disease at first time of diagnosis with about 30\% 5-year relative survival rate [27]. In addition, a few patients can develop metastasis many years after receiving radiotherapy or radical prostatectomy [28]. Currently, treatment of mCRPC is a very dynamic research focus area at both preclinical and clinical levels. Despite the wide variation of available options, there is no effective medication compared to the others [7]. Furthermore, incomplete understanding of the resistance mechanism to ADT makes mCRPC therapy very challenging [2].

In the past decade, ICIs displayed a durable response up to complete regression of metastatic lesions in different types of cancers such as melanoma and non-small cell lung carcinoma [29]. ICI agents have been investigated in urological cancers such as renal cell carcinoma, urothelial carcinoma, and prostate cancer, however their benefits in prostate cancer still need to be clarified [30]. Compared to melanoma, prostate cancer is immunologically cold with about 10 times less TMB. In addition, the hypoxic environment in the prostate is less attractive for infiltration by immune cells [31,32]. Therefore, this systematic review aimed to clarify the benefits of ICIs in mCRPC.

ICIs have been investigated as monotherapy as well as in different combination approaches, such as with chemotherapy or other ICI agents [22,24,26]. Chemotherapy might increase the tumor antigenicity, alter immune-suppressive pathways, and boost effector $\mathrm{T}$ cell responses. This points to the possibility of better outcomes when combining immunotherapy and anticancer agents [33,34]. The combination of cytotoxic T-lymphocyte antigen 4 (CTLA-4) and programmed death-1 (PD-1) blockade has been linked to better antitumor responses; in this context, it has been shown that ipilimumab, a monoclonal anti-CTLA4 antibody, increases tumor-infiltrating T cells and up-regulates the PD-1/PD-L1 inhibitory pathway in a compensatory fashion, implying that combination therapy may be very effective [35].

Survival benefits in unselected mCRPC patients seem to be modest. Our analysis displayed no benefit for OS, however ICIs might, at least, stabilize the disease, since the PFS was significantly better in patients treated with ICIs. The pleasant outcome is when there is prolongation of both OS and PFS, however the relationship between OS and PFS is not always directly correlated. Many factors such as the type of the disease and patients age and performance status can affect the direction of this relationship [36]. Another explanation is that the tumor microenvironment plays a fundamental role in response to immunotherapy. This microenvironment can be heterogeneous among prostate cancer patients, possibly leading to different degrees of response to checkpoint inhibitors [37]. These results must be interpreted cautiously due to the very limited number of studies involved and the heterogeneity in protocols and cohorts.

One of the challenging points regarding ICIs is the identification of real predicative biomarkers that can help in patient selection before starting the treatment. The identification of biomarkers is usually obtained from tissue biopsies that might not be available for every patient. In addition, long time preservation and technical processing might alter the molecular properties of the tissue samples [38]. PD-1/L1 expression has been investigated at an early stage in different types of cancers for correlation with response to ICIs. A PD-L1 immunohistochemistry test has been approved by the Food and Drug Administration (FDA) as a pretreatment diagnostic test, even though PD-L1 expression patterns are not a strong predictive biomarker for identifying other cancer types [39]. PD-1/L1 expression in prostate cancer tissues has been studied in a number of preclinical investigations and the results displayed that PD-L1 expression in tumors is variable and may rise as the tumor progresses [40]. In addition, radiotherapy can influence PD-L1 expression [41]. Therefore, patient selection for ICIs based on PD-1/L1 expression only might not represent an effective solution. In clinical studies, our pooled analysis displayed better ORR but no survival or PSA reduction benefits. Patients with partial response were considered responders according to the definition used by the included studies. Those patients might have a temporary response that was followed by disease relapse. Therefore, the better ORR 
observed does not change the conclusion of our study. Although we already answered this question, the results were based on different patient cohorts that underwent different treatment protocols.

DDR and TMB might be more reliable than PD-L expression as potential future predictive biomarkers. It is now recognized that somatic mutations impacting DNA repair genes are present in roughly $20-25 \%$ of metastatic prostate cancer patients [42]. Recent studies suggest that DNA damage can enhance the type I interferons (IFNs) system through the activation of the stimulator of interferon genes (STING) pathway. This, in turn, stimulates type I IFNs and cytosolic DNA sensors such as cyclic GMP-AMP synthase (cGAS), both of which effectively excite antitumor $\mathrm{T}$ cells $[43,44]$. Furthermore, concomitant genomic alterations such as homologous recombination deficiency (BRCA2, ATM, CDK12 mutations), can increase ICIs responsiveness by increasing TMB and neoantigen expression $[45,46]$. In addition, increased TMB might be associated with higher DDR, based on a study including 4129 prostate cancer patients [47]. In our results, DDR positivity was associated with significantly better PFS and a trend towards better OS. TMB was also associated with much higher ORR. Despite the limitations of our analysis, these results correlate with the previously mentioned thoughts regarding the possible role of the genetic-based response of mCRPC to ICIs.

The results of this systematic review and quantitative analysis are greatly limited by fundamental issues. For instance, the limited number of included studies, the number of patients, as well as the number of responders. Some studies are characterized by lack of randomization or control arm and incomplete reports. Additionally, different patients' inclusion criteria and previous exposure to different treatments such as radiotherapy, chemotherapy, and novel ADT agents were considered. Furthermore, subgroup analysis protocols were heterogeneous among studies. The short follow-up durations should also be taken into account.

In view of the current status of ICIs in MCRPC, genetic-based selection and profiling for patients might be a promising approach for further investigation of these inhibitors in $\mathrm{mCRPC}$ and to identify reliable predictive biomarkers.

\section{Conclusions}

The oncological benefits of checkpoint inhibitors in mCRPC are unfortunately limited. Currently, there is no reliable predictive biomarker to suggest better response in patients. Future randomized trials based on genetic profiling of the patients could help to discover definitive biomarkers for patient selection before offering immunotherapy.

Author Contributions: Conceptualisation: O.F., N.A.A. and G.C.; writing —original draft preparation, O.F., O.A.A.A., C.G.F. and G.C.; writing-review and editing, O.F., M.G.K.-A., U.A.F., C.G.F. and G.C.; visualisation, O.F., C.G.F. and G.C.; supervision, O.F., M.G.K.-A. and G.C.; funding acquisition, N.A.A., O.A.A.A. and U.A.F. All authors have read and agreed to the published version of the manuscript.

Funding: The authors gratefully acknowledge the Deanship of Scientific Research (DSR) at King Abdulaziz University, Jeddah, Saudi Arabia, for funding this project, under grant number (FP-027-43).

Institutional Review Board Statement: Not applicable.

Informed Consent Statement: Not applicable.

Data Availability Statement: Not applicable.

Acknowledgments: The authors acknowledge with thanks DSR for technical and financial support.

Conflicts of Interest: The authors declare no conflict of interest.

\section{References}

1. Sung, H.; Ferlay, J.; Siegel, R.L.; Laversanne, M.; Soerjomataram, I.; Jemal, A.; Bray, F. Global Cancer Statistics 2020: GLOBOCAN Estimates of Incidence and Mortality Worldwide for 36 Cancers in 185 Countries. CA Cancer J. Clin. 2021, 71, 209-249. [CrossRef] [PubMed] 
2. Fahmy, O.; Alhakamy, N.A.; Rizg, W.Y.; Bagalagel, A.; Alamoudi, A.J.; Aldawsari, H.M.; Khateb, A.M.; Eldakhakhny, B.M.; Fahmy, U.A.; Abdulaal, W.H.; et al. Updates on Molecular and Biochemical Development and Progression of Prostate Cancer. J. Clin. Med. 2021, 10, 5127. [CrossRef] [PubMed]

3. Russo, G.I.; Musso, N.; Romano, A.; Caruso, G.; Petralia, S.; Lanzanò, L.; Broggi, G.; Camarda, M. Challenging the Current Paradigm of Liquid Biopsy Through Dielectrophoresis (DEP) In Prostate Cancer. Preprints 2021, 2021120063. [CrossRef]

4. Swami, U.; McFarland, T.R.; Nussenzveig, R.; Agarwal, N. Advanced Prostate Cancer: Treatment Advances and Future Directions. Trends Cancer 2020, 6, 702-715. [CrossRef]

5. Gravis, G.; Fizazi, K.; Joly, F.; Oudard, S.; Priou, F.; Esterni, B.; Latorzeff, I.; Delva, R.; Krakowski, I.; Laguerre, B.; et al. Androgendeprivation therapy alone or with docetaxel in non-castrate metastatic prostate cancer (GETUG-AFU 15): A randomised, open-label, phase 3 trial. Lancet Oncol. 2013, 14, 149-158. [CrossRef]

6. James, N.D.; Sydes, M.R.; Clarke, N.W.; Mason, M.D.; Dearnaley, D.P.; Spears, M.R.; Ritchie, A.W.S.; Parker, C.C.; Russell, J.M.; Attard, G.; et al. Addition of docetaxel, zoledronic acid, or both to first-line long-term hormone therapy in prostate cancer (STAMPEDE): Survival results from an adaptive, multiarm, multistage, platform randomised controlled trial. Lancet 2016, 387, 1163-1177. [CrossRef]

7. Cornford, P.; van den Bergh, R.C.N.; Briers, E.; Van den Broeck, T.; Cumberbatch, M.G.; De Santis, M.; Fanti, S.; Fossati, N.; Gandaglia, G.; Gillessen, S.; et al. EAU-EANM-ESTRO-ESUR-SIOG Guidelines on Prostate Cancer. Part II-2020 Update: Treatment of Relapsing and Metastatic Prostate Cancer. Eur. Urol. 2021, 79, 263-282. [CrossRef]

8. Peng, T.R.; Lin, H.H.; Tsai, F.P.; Wu, T.W. Immune checkpoint inhibitors for first-line treatment of advanced non-small-cell lung cancer: A systematic review and network meta-analysis. Thorac. Cancer 2021, 12, 2873-2885. [CrossRef]

9. Da Silva, I.P.; Ahmed, T.; Reijers, I.L.; Weppler, A.M.; Warner, A.B.; Patrinely, J.R.; Serra-Bellver, P.; Allayous, C.; Mangana, J.; Nguyen, K. Ipilimumab alone or ipilimumab plus anti-PD-1 therapy in patients with metastatic melanoma resistant to anti-PD-(L) 1 monotherapy: A multicentre, retrospective, cohort study. Lancet Oncol. 2021, 22, 836-847. [CrossRef]

10. Fahmy, O.; Asri, K.; Schwentner, C.; Stenzl, A.; Gakis, G. Current status of robotic assisted radical cystectomy with intracorporeal ileal neobladder for bladder cancer. J. Surg. Oncol. 2015, 112, 427-429. [CrossRef] [PubMed]

11. Yekedüz, E.; Ertürk, İ.; Tural, D.; Karadurmuş, N.; Karakaya, S.; Hızal, M.; Arıkan, R.; Arslan, Ç.; Taban, H.; Küçükarda, A.; et al. Nivolumab in metastatic renal cell carcinoma: Results from the Turkish Oncology Group Kidney Cancer Consortium database. Future Oncol. 2021, 17, 4861-4869. [CrossRef] [PubMed]

12. Melo, C.M.; Vidotto, T.; Chaves, L.P.; Lautert-Dutra, W.; Reis, R.B.D.; Squire, J.A. The Role of Somatic Mutations on the Immune Response of the Tumor Microenvironment in Prostate Cancer. Int. J. Mol. Sci. 2021, 22, 9550. [CrossRef] [PubMed]

13. Pasero, C.; Gravis, G.; Guerin, M.; Granjeaud, S.; Thomassin-Piana, J.; Rocchi, P.; Paciencia-Gros, M.; Poizat, F.; Bentobji, M.; Azario-Cheillan, F.; et al. Inherent and Tumor-Driven Immune Tolerance in the Prostate Microenvironment Impairs Natural Killer Cell Antitumor Activity. Cancer Res. 2016, 76, 2153-2165. [CrossRef] [PubMed]

14. Moher, D.; Shamseer, L.; Clarke, M.; Ghersi, D.; Liberati, A.; Petticrew, M.; Shekelle, P.; Stewart, L.A. Preferred reporting items for systematic review and meta-analysis protocols (PRISMA-P) 2015 statement. Syst. Rev. 2015, 4, 1. [CrossRef] [PubMed]

15. Caruso, G.; Godos, J.; Castellano, S.; Micek, A.; Murabito, P.; Galvano, F.; Ferri, R.; Grosso, G.; Caraci, F. The Therapeutic Potential of Carnosine/Anserine Supplementation against Cognitive Decline: A Systematic Review with Meta-Analysis. Biomedicines 2021, 9, 253. [CrossRef]

16. Therasse, P.; Arbuck, S.G.; Eisenhauer, E.A.; Wanders, J.; Kaplan, R.S.; Rubinstein, L.; Verweij, J.; Van Glabbeke, M.; Van Oosterom, A.T.; Christian, M.C.; et al. New Guidelines to Evaluate the Response to Treatment in Solid Tumors. J. Natl. Cancer Inst. 2000, 92, 205-216. [CrossRef]

17. Tierney, J.F.; Stewart, L.A.; Ghersi, D.; Burdett, S.; Sydes, M.R. Practical methods for incorporating summary time-to-event data into meta-analysis. Trials 2007, 8, 16. [CrossRef]

18. Lazzarino, G.; Listorti, I.; Muzii, L.; Amorini, A.M.; Longo, S.; Di Stasio, E.; Caruso, G.; D’Urso, S.; Puglia, I.; Pisani, G.; et al. Low-molecular weight compounds in human seminal plasma as potential biomarkers of male infertility. Hum. Reprod. 2018, 33, 1817-1828. [CrossRef] [PubMed]

19. Sharma, P.; Pachynski, R.K.; Narayan, V.; Fléchon, A.; Gravis, G.; Galsky, M.D.; Mahammedi, H.; Patnaik, A.; Subudhi, S.K.; Ciprotti, M.; et al. Nivolumab Plus Ipilimumab for Metastatic Castration-Resistant Prostate Cancer: Preliminary Analysis of Patients in the CheckMate 650 Trial. Cancer Cell 2020, 38, 489-499. [CrossRef]

20. Boudadi, K.; Suzman, D.L.; Anagnostou, V.; Fu, W.; Luber, B.; Wang, H.; Niknafs, N.; White, J.R.; Silberstein, J.L.; Sullivan, R.; et al. Ipilimumab plus nivolumab and DNA-repair defects in AR-V7-expressing metastatic prostate cancer. Oncotarget 2018, 9, 28561-28571. [CrossRef]

21. Antonarakis, E.S.; Piulats, J.M.; Gross-Goupil, M.; Goh, J.; Ojamaa, K.; Hoimes, C.J.; Vaishampayan, U.; Berger, R.; Sezer, A.; Alanko, T.; et al. Pembrolizumab for Treatment-Refractory Metastatic Castration-Resistant Prostate Cancer: Multicohort, Open-Label Phase II KEYNOTE-199 Study. J. Clin. Oncol. 2020, 38, 395-405. [CrossRef] [PubMed]

22. Karzai, F.; VanderWeele, D.; Madan, R.A.; Owens, H.; Cordes, L.M.; Hankin, A.; Couvillon, A.; Nichols, E.; Bilusic, M.; Beshiri, M.; et al. Activity of durvalumab plus olaparib in metastatic castration-resistant prostate cancer in men with and without DNA damage repair mutations. J. Immunother. Cancer 2018, 6, 141. [CrossRef] [PubMed] 
23. Beer, T.M.; Kwon, E.D.; Drake, C.G.; Fizazi, K.; Logothetis, C.; Gravis, G.; Ganju, V.; Polikoff, J.; Saad, F.; Humanski, P.; et al. Randomized, Double-Blind, Phase III Trial of Ipilimumab Versus Placebo in Asymptomatic or Minimally Symptomatic Patients With Metastatic Chemotherapy-Naive Castration-Resistant Prostate Cancer. J. Clin. Oncol. 2017, 35, 40-47. [CrossRef] [PubMed]

24. Kwon, E.D.; Drake, C.G.; Scher, H.I.; Fizazi, K.; Bossi, A.; Van den Eertwegh, A.J.; Krainer, M.; Houede, N.; Santos, R.; Mahammedi, H. Ipilimumab versus placebo after radiotherapy in patients with metastatic castration-resistant prostate cancer that had progressed after docetaxel chemotherapy (CA184-043): A multicentre, randomised, double-blind, phase 3 trial. Lancet Oncol. 2014, 15, 700-712. [CrossRef]

25. Sweeney, C.J.; Gillessen, S.; Rathkopf, D.; Matsubara, N.; Drake, C.; Fizazi, K.; Piulats, J.M.; Wysocki, P.J.; Buchschacher, G.L.; Doss, J.; et al. Abstract CT014: IMbassador250: A phase III trial comparing atezolizumab with enzalutamide vs enzalutamide alone in patients with metastatic castration-resistant prostate cancer (mCRPC). Cancer Res. 2020, 80, CT014. [CrossRef]

26. Hotte, S.; Winquist, E.; Chi, K.; Ellard, S.; Sridhar, S.; Emmenegger, U.; Salim, M.; Iqbal, N.; Canil, C.; Kollmannsberger, C.; et al. CCTG IND 232: A phase II study of durvalumab with or without tremelimumab in patients with metastatic castration resistant prostate cancer (mCRPC). Ann. Oncol. 2019, 30, v885. [CrossRef]

27. Siegel, D.A.; O’Neil, M.E.; Richards, T.B.; Dowling, N.F.; Weir, H.K. Prostate Cancer Incidence and Survival, by Stage and Race/Ethnicity-United States, 2001-2017. Morb. Mortal. Wkly. Rep. 2020, 69, 1473-1480. [CrossRef]

28. Marvaso, G.; Volpe, S.; Pepa, M.; Augugliaro, M.; Corrao, G.; Biffi, A.; Zaffaroni, M.; Bergamaschi, L.; La Fauci, F.M.; Mistretta, F.A.; et al. Oligorecurrent Prostate Cancer and Stereotactic Body Radiotherapy: Where Are We Now? A Systematic Review and Meta-analysis of Prospective Studies. Eur. Urol. Open Sci. 2021, 27, 19-28. [CrossRef] [PubMed]

29. Parikh, R.B.; Min, E.J.; Wileyto, E.P.; Riaz, F.; Gross, C.P.; Cohen, R.B.; Hubbard, R.A.; Long, Q.; Mamtani, R. Uptake and Survival Outcomes Following Immune Checkpoint Inhibitor Therapy Among Trial-Ineligible Patients With Advanced Solid Cancers. JAMA Oncol. 2021, 7, 1843-1850. [CrossRef]

30. Grimm, M.O.; Gottschlich, T.; Ali, N.; Foller, S.; Leucht, K. Side effects of immune checkpoint inhibitor treatment of urological tumors. Urologe A. 2021, 60, 803-815. [CrossRef]

31. Berger, M.F.; Lawrence, M.S.; Demichelis, F.; Drier, Y.; Cibulskis, K.; Sivachenko, A.Y.; Sboner, A.; Esgueva, R.; Pflueger, D.; Sougnez, C.; et al. The genomic complexity of primary human prostate cancer. Nature 2011, 470, 214-220. [CrossRef] [PubMed]

32. Jayaprakash, P.; Ai, M.; Liu, A.; Budhani, P.; Bartkowiak, T.; Sheng, J.; Ager, C.; Nicholas, C.; Jaiswal, A.R.; Sun, Y.; et al. Targeted hypoxia reduction restores $\mathrm{T}$ cell infiltration and sensitizes prostate cancer to immunotherapy. J. Clin. Investig. 2018, 128, 5137-5149. [CrossRef]

33. Apetoh, L.; Ladoire, S.; Coukos, G.; Ghiringhelli, F. Combining immunotherapy and anticancer agents: The right path to achieve cancer cure? Ann. Oncol. 2015, 26, 1813-1823. [CrossRef] [PubMed]

34. Fournier, C.; Rivera Vargas, T.; Martin, T.; Melis, A.; Apetoh, L. Immunotherapeutic properties of chemotherapy. Curr. Opin. Pharmacol. 2017, 35, 83-88. [CrossRef] [PubMed]

35. Intlekofer, A.M.; Thompson, C.B. At the Bench: Preclinical rationale for CTLA-4 and PD-1 blockade as cancer immunotherapy. J. Leukoc. Biol. 2013, 94, 25-39. [CrossRef]

36. Hess, L.M.; Brnabic, A.; Mason, O.; Lee, P.; Barker, S. Relationship between Progression-free Survival and Overall Survival in Randomized Clinical Trials of Targeted and Biologic Agents in Oncology. J. Cancer 2019, 10, 3717-3727. [CrossRef]

37. Meng, J.; Zhou, Y.; Lu, X.; Bian, Z.; Chen, Y.; Zhou, J.; Zhang, L.; Hao, Z.; Zhang, M.; Liang, C. Immune response drives outcomes in prostate cancer: Implications for immunotherapy. Mol. Oncol. 2021, 15, 1358-1375. [CrossRef] [PubMed]

38. Patel, S.P.; Kurzrock, R. PD-L1 Expression as a Predictive Biomarker in Cancer Immunotherapy. Mol. Cancer Ther. 2015, 14, 847-856. [CrossRef] [PubMed]

39. Jiang, Y.; Chen, M.; Nie, H.; Yuan, Y. PD-1 and PD-L1 in cancer immunotherapy: Clinical implications and future considerations. Hum. Vaccines Immunother. 2019, 15, 1111-1122. [CrossRef]

40. Geng, L.; Huang, D.; Liu, J.; Qian, Y.; Deng, J.; Li, D.; Hu, Z.; Zhang, J.; Jiang, G.; Zheng, S. B7-H1 up-regulated expression in human pancreatic carcinoma tissue associates with tumor progression. J. Cancer Res. Clin. Oncol. 2008, 134, 1021-1027. [CrossRef] [PubMed]

41. Chen, D.; Barsoumian, H.B.; Yang, L.; Younes, A.I.; Verma, V.; Hu, Y.; Menon, H.; Wasley, M.; Masropour, F.; Mosaffa, S.; et al. SHP-2 and PD-L1 Inhibition Combined with Radiotherapy Enhances Systemic Antitumor Effects in an Anti-PD-1-Resistant Model of Non-Small Cell Lung Cancer. Cancer Immunol. Res. 2020, 8, 883-894. [CrossRef] [PubMed]

42. Abida, W.; Armenia, J.; Gopalan, A.; Brennan, R.; Walsh, M.; Barron, D.; Danila, D.; Rathkopf, D.; Morris, M.; Slovin, S.; et al. Prospective Genomic Profiling of Prostate Cancer Across Disease States Reveals Germline and Somatic Alterations That May Affect Clinical Decision Making. JCO Precis. Oncol. 2017, 1, 1-16. [CrossRef] [PubMed]

43. Chen, Q.; Sun, L.; Chen, Z.J. Regulation and function of the Cgas-STING pathway of cytosolic DNA sensing. Nat. Immunol. 2016, 17, 1142-1149. [CrossRef]

44. Hartlova, A.S.; Erttmann, S.F.; Raffi, F.A.; Schmalz, A.M.; Resch, U.; Anugula, S.; Lienenklaus, S.; Nilsson, L.M.; Kröger, A.; Nilsson, J.A.; et al. DNA Damage Primes the Type I Interferon System via the Cytosolic DNA Sensor STING to Promote Anti-Microbial Innate Immunity. Immunity 2015, 42, 332-343. [CrossRef] [PubMed] 
45. Strickland, K.C.; Howitt, B.E.; Shukla, S.A.; Rodig, S.; Ritterhouse, L.L.; Liu, J.F.; Garber, J.E.; Chowdhury, D.; Wu, C.J.; D’Andrea, A.D.; et al. Association and prognostic significance of BRCA1/2-mutation status with neoantigen load, number of tumorinfiltrating lymphocytes and expression of PD-1/PD-L1 in high grade serous ovarian cancer. Oncotarget 2016, 7, 13587-13598. [CrossRef] [PubMed]

46. Taylor, R.; Fraser, M.; Livingstone, J.; Espiritu, S.M.G.; Thorne, H.; Huang, V.; Lo, W.; Shiah, Y.-J.; Yamaguchi, T.N.; Sliwinski, A.; et al. Germline BRCA2 mutations drive prostate cancers with distinct evolutionary trajectories. Nat. Commun. 2017, 8, 13671. [CrossRef]

47. Wang, F.; Zhao, Q.; Wang, Y.-N.; Jin, Y.; He, M.-M.; Liu, Z.-X.; Xu, R.-H. Evaluation of POLE and POLD1 Mutations as Biomarkers for Immunotherapy Outcomes Across Multiple Cancer Types. JAMA Oncol. 2019, 5, 1504-1506. [CrossRef] [PubMed] 